\title{
LITERASI DIGITAL DAN PERAN STRATEGIS NET GENERATION DALAM MEMBANGUN KONTEN POSITIF DI MEDIA SOSIAL
}

\section{DIGITAL LITERACY AND STRATEGIC ROLE OF NET GENERATION TO CREAT POSITIVE CONTENTS IN SOCIAL MEDIA}

\author{
Athik Hidayatul Ummah ${ }^{1}$, Andri Kurniawan ${ }^{2)}$ \\ ${ }^{1,2}$ Universitas Islam Negeri Mataram \\ ${ }^{1}$ Email: athika_hidayah@uinmataram.ac.id
}

\begin{abstract}
Abstrak: Perkembangan teknologi dan informasi telah membawa berbagai dampak dalam kehidupan manusia. Terutama bagi generasi muda yang lahir dan tumbuh dalam perkembangan teknologi. Kemampuan membaca generasi internet (net generation) perlu diarahkan pada pemahaman terkait informasi digital dan pemanfaatan berbagai platform media digital. Literasi digital merupakan kemampuan atau keterampilan seseorang untuk memahami dan menggunakan informasi dari berbagai sumber digital. Tujuan kegiatan pengabdian ini adalah untuk meningkatkan kompetensi literasi digital generasi muda melalui pelatihan literasi digital. Kompetensi pelatihan literasi digital yaitu: pertama, kemampuan mengakses dan memanfaatkan jurnal serta buku elektronik; kedua, kemampuan untuk mengidentifikasi dan menganalisa informasi yang benar atau palsu (hoax); dan ketiga, kemampuan membuat konten positif. Adapun hasil dari pelatihan literasi digital menunjukkan terjadi peningkatan kompetensi peserta pelatihan dari yang sebelumnya kurang memiliki kompetensi (37\%) menjadi memiliki kompetensi literasi digital yang baik (72\%). Capaian dari kegiatan pengabdian ini sesuai dengan tiga kompetensi yang diharapakan. Jika kompetensi ini dimiliki, maka konten positif bisa disebarluaskan kepada khalayak di media sosial.
\end{abstract}

Kata Kunci: Literasi Digital, Generasi Internet, Hoax, Konten Positif

Abstract: Technology and information development has brought various impacts in human life. Especially for youth who are born and growth in technological development. They are net generation. Reading competence for net generation needs to be directed to understanding about digital information and competence about using of digital media platforms. Digital literacy is a person's ability or skill to understand and use information from various digital sources. The purpose of this community service is to increase the digital literacy competence of the net generation through digital literacy training. The competencies of digital literacy training are: first, the ability to access and use journals and electronic books; second, the ability to analyze and identify true or false information; and third, the ability to create positive content. The results of digital literacy training are the competency of trainees or participants increase. This is indicated the percentage that before traning the trainees have lacked competency (37\%). Then, after literacy digital traning the traineees have good digital literacy competence (72\%). Furthemore, the achievements of the community service are appropiate with the three competencies expected. If they have this competencies, they can create positive content to spread on social media to public.

Keywords: Digital Literacy, Net Generation, Hoax, Positive Content 
INTEGRITAS : Jurnal Pengabdian

Vol 4, No 2, Desember 2020

ISSN 2580 - 7978 (cetak) ISSN 2615 - 0794 (online)

\section{PENDAHULUAN}

Kehidupan masyarakat saat ini tidak dapat dipisahkan dari teknolog digital dan internet. Setiap tahun jumlah pengguna internet semakin bertambah. Sebagian besar pengguna internet adalah net generation, yaitu generasi yang lahir dan tumbuh dalam perkembangan teknologi. Teori net generation menunjukkan bahwa mereka yang lahir setelah 1985 adalah generasi yang sangat paham dengan teknologi serta mahir dalam menangani teknologi maupun internet. Mereka terbiasa berselancar dengan internet dan bekerja dengan menggunakan perangkat teknologi komputer maupun digital (Narasuman et all, 2011).

Menurut laporan We Are Social (2019), di Indonesia ada 150 juta pengguna internet dan aktif di media sosial. Adapun pengguna internet dan media sosial paling banyak berada pada usia 18 sampai 34 tahun. Dalam mengakses media, mereka menghabiskan waktu rata-rata 8 jam 36 menit. Sementara menurut APJII atau Asosiasi Penyelenggara Jasa Internet Indonesia (2019), dari segmen umur penetrasi internet tiga paling tinggi ada pada kelompok usia 15 hingga 19 tahun (mencapai 91\%), usia 20-24 tahun (88,5\%), dan 25-29 tahun (82,7\%). Pada rentang usia ini mereka adalah net generation.

Banyaknya pengguna internet terutama di kalangan anak muda bukan berarti tanpa masalah. Internet dapat membantu dan mempermudah aktivitas atau pekerjaan manusia. Pencarian sumber belajar dan informasi yang dibutuhkan lebih mudah dan cepat didapatkan. Pertukaran informasi dan media komunikasi dapat dilakukan tanpa dibatasi jarak fisik. Akan tetapi, internet juga memberikan dampak negatif bagi yang tidak bijak menggunakannya. Seperti: kecanduan (adiksi), pelanggaran privasi, penipuan, pornografi, penyebaran informasi palsu atau hoax yang marak terjadi, dan lain sebagainya.

Sejumlah penyalahgunaan internet terjadi karena rendahnya literasi digital masyarakat. Kurnia dan Astuti (2017) menyatakan dalam hasil temuannya bahwa kelompok remaja dan pelajar merupakan sasaran utama kegiatan literasi digital. Kelompok ini dianggap paling rentan mendapatkan dampak negatif media digital. Namun disisi lain, jika kelompok ini mendapatkan pendidikan yang tepat, maka 


\section{INTEGRITAS : Jurnal Pengabdian}

Vol 4, No 2, Desember 2020

ISSN 2580 - 7978 (cetak) ISSN 2615 - 0794 (online)

dapat berpotensi sebagai agen perubahan yang membantu mengatasi berbagai persoalan masyarakat digital.

Gerakan literasi digital saat ini menjadi gerakan nasional untuk menghadapi tantangan digital di era industri 4.0. Tujuannya untuk mendorong pengguna internet agar lebih cerdas, bijak dan bertanggung jawab dalam menggunakan teknologi dan internet. Literasi digital juga akan menciptakan kehidupan masyarakat dengan pola pikir yang kritis dan kreatif. Masyarakat tidak akan mudah terprovokasi atau termakan isu-isu yang tidak benar atau hoax. Namun, pada kenyataanya hoax masih sering tersebar secara masif di berbagai platform media sosial dan menjadi wabah hoax.

Berdasarkan hasil survey Mastel (2017) kepada 1.116 responden secara online, diklasifikasi hoax sebagai: berita bohong yang disengaja (90.3\%); berita yang menghasut (61.6\%); berita yang tidak akurat (59\%); berita ramalan (14\%); berita yang menyudutkan (12.6\%). Sementara itu saluran penyebaran hoax yaitu 92.4\% dari media sosial, $62.8 \%$ dari aplikasi chat, $34.9 \%$ situs web, $8.7 \%$ dari televisi, $5 \%$ dari media cetak $3.1 \%$ dari email. Adapun informasi hoax hampir ada di semua isu, tiga dominan yaitu isu sosial politik (91.8\%), suku ras dan agama $(88.6 \%)$, dan kesehatan (41.2\%), lainnya seperti makanan dan minuman, penipuan keuangan, iptek, berita duka, candaan, bencana alam, dan lalu lintas.

Sementara itu, pada tahun 2018 Bawaslu RI menyebutkan bahwa potensi peredaran hoax dan ujaran kebencian yang tinggi ada di 12 (dua belas) provinsi, salah satunya Nusa Tenggara Barat (NTB). Kedua, menurut SAFEnet (2018), laporan pelanggaran UU ITE (Informasi dan Transaksi Elektronik) menempatkan NTB sebagai provinsi dengan jumlah kasus terbanyak di luar pulau Jawa. Tercatat ada 14 kasus yang pernah terjadi. Sebanyak 29,4\% terlapor berasal dari kelompok awam, aktivis $(8,2 \%)$, pelajar dan mahasiswa $(6,5 \%)$, guru dan dosen $(6,1 \%)$, jurnalis $(5,3 \%)$.

Generasi muda yang sedang bereuforia dengan internet dan media sosial cenderung tidak mengenali mana informasi yang benar dan hoax. Padahal banyak situs yang sudah dibuat oleh pemerintah maupun lembaga media massa untuk mengecek keakuratan informasi. Selain itu, fenomena kecanduan internet (internet addiction) di kalangan anak muda cenderung membawa sejumlah dampak negatif. 
INTEGRITAS : Jurnal Pengabdian

Vol 4, No 2, Desember 2020

ISSN 2580 - 7978 (cetak) ISSN 2615 - 0794 (online)

Padahal perkembangan teknologi dan informasi harusnya disadari sebagai peluang untuk lebih produktif dan kreatif.

Kemampuan membaca generasi muda perlu diarahkan dan ditingkatkan pada pemahaman arus informasi digital dan kecerdasan dalam menggunakan platform media digital. Peningkatan kompetensi literasi digital dapat dilakukan melalui upaya pendidikan atau pelatihan. Upaya ini sangat penting agar masyarakat terutama generasi muda mampu memanfaatkan teknologi dan internet untuk hal-hal yang bermanfaat. Dengan memiliki kompetensi literasi digital, seseorang dapat mengakses informasi secera efektif dan efisien, melakukan penilaian terhadap informasi secara kritis, serta menggunakan informasi tersebut untuk hal-hal yang bermanfaat.

Literasi digital dipopulerkan oleh Paul Gilster sejak tahun 1997. Menurutnya Gilster, literasi digital adalah kemampuan atau keterampilan seseorang untuk memahami dan menggunakan informasi dari berbagai sumber digital. Sementara menurut Hague (2010:2), literasi digital adalah kemampuan menggunakan teknologi digital untuk mengoperasikan perangkat teknologi informasi dan komunikasi dan kemampuan berkomunikasi lebih efektif dalam berbagai bentuk. Jadi, literasi digital merupakan sikap, pemahaman, keterampilan, serta kemampuan memanfaatkan media baru atau internet untuk mendapatkan dan mengkomunikasikan informasi secara efektif. Keterampilan tersebut termasuk mengumpulkan, menyeleksi, serta mengevaluasi segala informasi, kemudian membentuknya menjadi pengetahuan baru atau opini yang kuat.

Menurut Gilster (1997:3) kompetensi literasi digital dibagi ke dalam empat kompetensi inti yang perlu dimiliki oleh seseorang, yaitu:

1. Pencarian di internet (internet searching); kemampuan untuk menggunakan internet dan melakukan berbagai aktivitas didalamnya.

2. Pandu arah (hypertextual navigation); keterampilan untuk membaca serta pemahaman secara dinamis terkait hypertext dan perangkatnya. Kompetensi: (a) Pengetahuan hypertext dan hyperlink beserta cara kerjanya. (b) Pengetahuan perbedaan membaca buku teks dengan buku elektronik atau 


\section{INTEGRITAS : Jurnal Pengabdian}

Vol 4, No 2, Desember 2020

ISSN 2580 - 7978 (cetak) ISSN 2615 - 0794 (online)

browsing melalui internet. (c) Pengetahuan tentang cara kerja website (d) Kemampuan memahami karakteristik halaman website.

3. Evaluasi konten informasi (content evaluation); kemampuan berfikir kritis dan memberikan penilaian terhadap apa yang ditemukan secara online, serta kemampuan untuk mengidentifikasi kelengkapan maupun informasi. Kompetensi: (a) Kemampuan membedakan antara tampilan dengan konten informasi yakni persepsi dalam memahami tampilan halaman website. (b) Kemampuan menganalisis latar belakang informasi di internet yakni kesadaran menelusuri lebih jauh mengenai sumber dan pembuat informasi. (c) Kemampuan mengevaluasi alamat website dengan cara memahami macam-macam domain. (d) Kemampuan menganalisis halaman website. (e) Pengetahuan tentang FAQ dalam suatu newsgroup/grup diskusi.

4. Penyusunan pengetahuan (knowledge assembly); kemampuan menyusun pengetahuan, membangun suatu kumpulan informasi yang diperoleh dari berbagai sumber, dan kemampuan untuk mengumpulkan dan mengevaluasi fakta dan opini dengan baik. Kompetensi: (a) Kemampuan membuat personal newsfeed atau pemberitahuan berita terbaru melalui newsgroup, mailing list, dll. (b) Kemampuan melakukan analisis terhadap informasi yang diperoleh. (c). Kemampuan menggunakan semua jenis media untuk membuktikan kebenaran informasi. (d). Kemampuan menyusun sumber informasi yang diperoleh di internet dengan kehidupan nyata.

Sementara menurut Davis \& Shaw (2011) terdapat enam (6) kompetensi utama literasi digital, meliputi: (1) pemahaman format digital dan non digital; (2) penciptaan dan komunikasi informasi digital; (3) evaluasi informasi; (4) penghimpunan atau perakitan pengetahuan; (5) literasi informasi; dan (6) literasi media. Kompetensi literasi digital menjadi sebuah indikator dan alat ukur kemampuan seseorang hingga dapat dikatakan memiliki kemampuan literasi digital. Kompetensi literasi digital menjadi sebuah kemampuan, keterampilan, yang bergabung dengan pengalaman dalam menggunakan teknologi digital.

Dapat disimpulkan, bahwa kompetensi literasi digital adalah kemampuan yang harus dimiliki seseorang untuk dapat menyikapi kemajuan media digital yang meliputi kemampuan dan keterampialan dalam mencari informasi di internet, 
INTEGRITAS : Jurnal Pengabdian

Vol 4, No 2, Desember 2020

ISSN 2580 - 7978 (cetak) ISSN 2615 - 0794 (online)

keterampilan untuk membaca serta pemahaman secara dinamis terhadap lingkungan website, mengevaluasi konten informasi dari media digital, dan kemampuan menyusun pengetahuan atau kumpulan informasi yang diperoleh dari berbagai sumber dan media digital.

Tujuan kegiatan pengabdian ini adalah untuk meningkatkan kompetensi literasi digital generasi muda atau net generation melalui pelatihan literasi digital. Adapun kompetensi yang ingin dicapai diramu dalam dua kompetensi utama, yaitu: Kompetensi utama pelatihan literasi digital yaitu: pertama, kemampuan mengakses dan memanfaatkan jurnal serta buku elektronik; kedua, kemampuan untuk menganalisa dan mengidentifikasi informasi yang benar atau palsu (hoax); dan ketiga, kemampuan membuat konten positif.

\section{METODE}

Berdasarkan paparan pada pendahuluan, pelatihan literasi digital dilakukan sebagai solusi untuk meningkatkan pemahaman literasi digital pada generasi muda. Berdasarkan pengamatan dan wawancara awal yang dilakukan, banyak anak-anak muda, terutama pelajar atau mahasiswa semester awal kurang memiliki kemampuan literasi digital yang baik. Hal itu ditunjukkan dari adanya kesulitan dalam mengakses sumber rujukan atau referensi pembelajaran yang benar. Padahal ini menjadi kebutuhan akademik mereka. Selain itu adanya kesulitan membedakan informasi yang benar dan hoax yang tersebar di media sosial. Mereka cenderung membagikan konten tanpa melakukan cek dan ricek sumber kebenaran informasi.

Setelah mengumpulkan informasi melalui pengamatan dan wawancara, kemudian disusun kegiatan pelatihan literasi digital. Adapun kegiatan yang dilakukan sebelum pelatihan yaitu: Pertama, menyusun pre-tes, post-test, dan materi pelatihan. Kedua, penyebaran undangan pelatihan. Ada beberapa kriteria untuk mengikuti pelatihan literasi digital, yaitu: generasi muda pada rentang usia 18 sampai 22 tahun; lulus SMA atau mahasiswa semester pertama; belum pernah mengikuti pelatihan literasi digital; dan bersedia mengikuti pelatihan. Kriteria ini dibuat untuk memfokuskan subyek pelatihan yang memiliki kultur digital yang serupa. Tahapan yang dilakukan dalam pelatihan literasi digital, diantaranya: 


\section{INTEGRITAS : Jurnal Pengabdian}

Vol 4, No 2, Desember 2020

ISSN $2580-7978$ (cetak) ISSN 2615 - 0794 (online)

1. Pre-test untuk mengetahui kondisi kemampuan atau pengetahuan awal peserta pelatihan mengenai literasi digital. Pre-test diberikan melalui kuisioner, lalu diperkuat dengan diskusi dan refleksi awal. Pre-test dilakukan sebelum kegiatan pelatihan.

2. Pelatihan literasi digital dibagi dalam dua sesi. Sesi I membahas materi tentang "Memanfaatkan Internet: Kunci Sukses Akademik". Sesi II membahas materi tentang "Cerdas Memilih Media dan Bijak Menyebarkan Informasi”. Materi ini diberikan sesuai dengan kebutuhan peserta pelatihan.

3. Post-tes untuk mengetahui gambaran tentang kemampuan yang dicapai oleh peserta setelah berakhirnya pelatihan.

4. Evaluasi dan follow-up. Evalusi penting dilakukan untuk mengetahui seberapa besar efektivitas (keterlaksanaan dan ketercapaian) pelatihan literasi digital yang telah dilaksanakan. Sementara follow-up dilakukan sebagai langkah tindak lanjut dan komitmen yang dibangun setelah pelatihan.

\section{HASIL DAN PEMBAHASAN}

Pelatihan literasi digital dilaksanakan di jurusan Komunikasi dan Penyiaran Islam Universitas Islam Negeri Mataram, pada tanggal 10-11 Oktober 2019. Pelatihan dilakukan dalam dua hari dengan durasi setiap pertemuan empat (4) jam. Pertemuan dilakukan dalam dua kali pertemuan untuk menghindari kejenuhan berdasarkan kesepakatan dengan peserta pelatihan. Pertemuan pertama, kegiatan pre-test dan materi sesi I. Pertemuan kedua yaitu kegiatan materi sesi II, post-test, lalu dilanjutkan evaluasi dan follow up. Adapun jumlah peserta pelatihan berjumlah 25 orang, dengan rincian peserta laki-laki berjumlah 11 orang dan perempuan berjumlah 14 orang. Mereka berasal dari berbagai kota/kabupaten di Pulau Lombok, diantaranya kota Mataram, Lombok Tengah, Lombok Barat, Lombok Utara, dan Lombok Timur. Mereka adalah mahasiswa semester pertama dan memiliki latarbelakang pendidikan sekolah menengah atas yang beragam, ada yang dari SMA, MA, maupun SMK.

Pada tahap penyusunan pre-test dan post-test serta materi pelatihan, kompetensi literasi digital Gilster digunakan dalam menyusun instrument pre-test dan post-test.Instrumen pengukuran ini digunakan untuk mengetahui keberhasilan 


\section{INTEGRITAS : Jurnal Pengabdian}

Vol 4, No 2, Desember 2020

ISSN 2580 - 7978 (cetak) ISSN 2615 - 0794 (online)

kegiatan pelatihan secara kuantitatif. Instrumen pre-test dan post-test terdiri dari 25 soal dengan menggunakan jawaban pilihan sesuai dengan kondisi peserta. Pretest diberikan sebelum pelatihan, dan post-tes diberikan setelah pelatihan. Kegiatan ini bertujuan untuk mengetahui perubahan kemampuan literasi digital para peserta sebelum dan sesudah pelatihan. Selain itu juga disusun panduan serta materi pelatihan literasi digital untuk mempermudah peserta mengikuti dan memahami materi pelatihan.

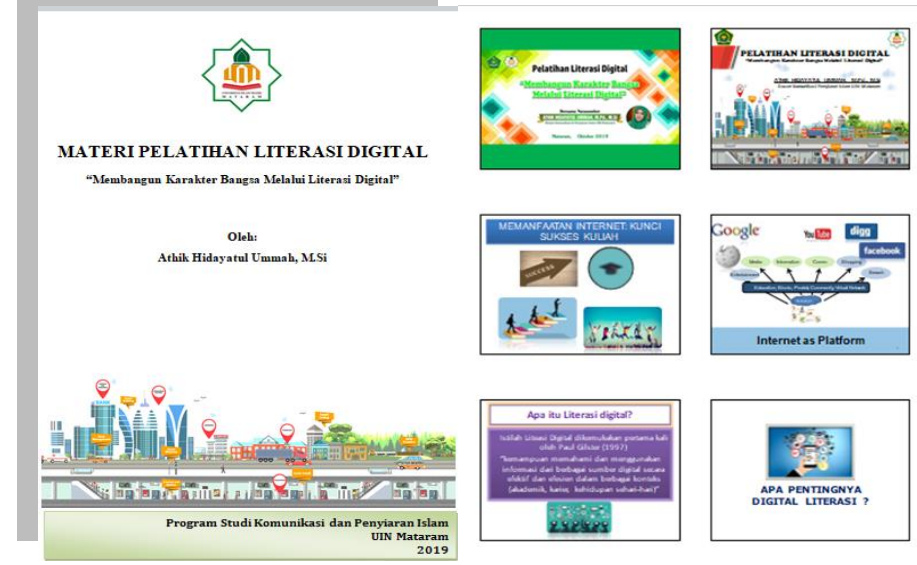

Gambar 1. Panduan dan Materi Pelatihan Literasi digital

Ada beberapa temuan menarik pada proses pelatihan literasi digital. Pertama, pada tahap pre-test, setelah mengisi instrumen pre-test peserta digali informasi dan pengetahuan awalnya lebih dalam melalui diskusi terkait dengan literasi digital dan apa pentingnya literasi digital. Banyak diantara peserta pelatihan belum mengetahui secara benar bagaimana literasi digital, walaupun sangat familiar atau sering mendengar kata literasi digital. Oleh karena itu, peserta pelatihan berkomitmen dan bersungguh-sungguh mengikuti setiap tahap pelatihan agar mendapatkan pemahaman yang utuh terkait literasi digital. Selain itu mereka tertarik karena belum pernah mendapatkan pelatihan.

Kedua, pada tahapan pelatihan sesi ke II. Sebelum masuk materi, peserta diajak berdialog terkait media sosial yang sudah digunakan, bagaimana pemanfaatan media sosial mereka selama ini, dan terkait dengan informasi yang mereka dapatkan dan sebarkan dalam media sosial. Pada hasil pre-test menunjukkan, pada pertanyaan 'apakah Anda pernah menyebarkan berita hoax?'. Hasilnya sebanyak 4\% menjawab "iya", 28\% menjawab "mungkin", dan 68\% 


\section{INTEGRITAS : Jurnal Pengabdian}

Vol 4, No 2, Desember 2020

\section{ISSN $2580-7978$ (cetak) ISSN 2615 - 0794 (online)}

menjawab "tidak pernah". Namun setelah digali lebih dalam diskusi, ternyata yang menjawab tidak pernah menyebar berita hoax memikirkan ulang jawabannya. Hal itu dikarenakan, tanpa disadari mereka sebenarnya sering menyebar informasi tanpa menelusuri kebenaran sumber informasi tersebut. Sementara mereka yang tidak mengetahui atau mengenali ciri-ciri berita hoax atau informasi palsu sebanyak 24\%. Yang menjawab "mungkin" sangat tinggi sebesar $64 \%$, dan yang menjawab "ya" hanya 12\%. Sementara informasi yang sering mereka dapatkan lebih banyak dari facebook sebesar 52\% dan 32\% mendapatkan dari situs berita online, sisanya tersebar di media sosial lainnya. Berikut kegiatan pelatihan literasi digital.

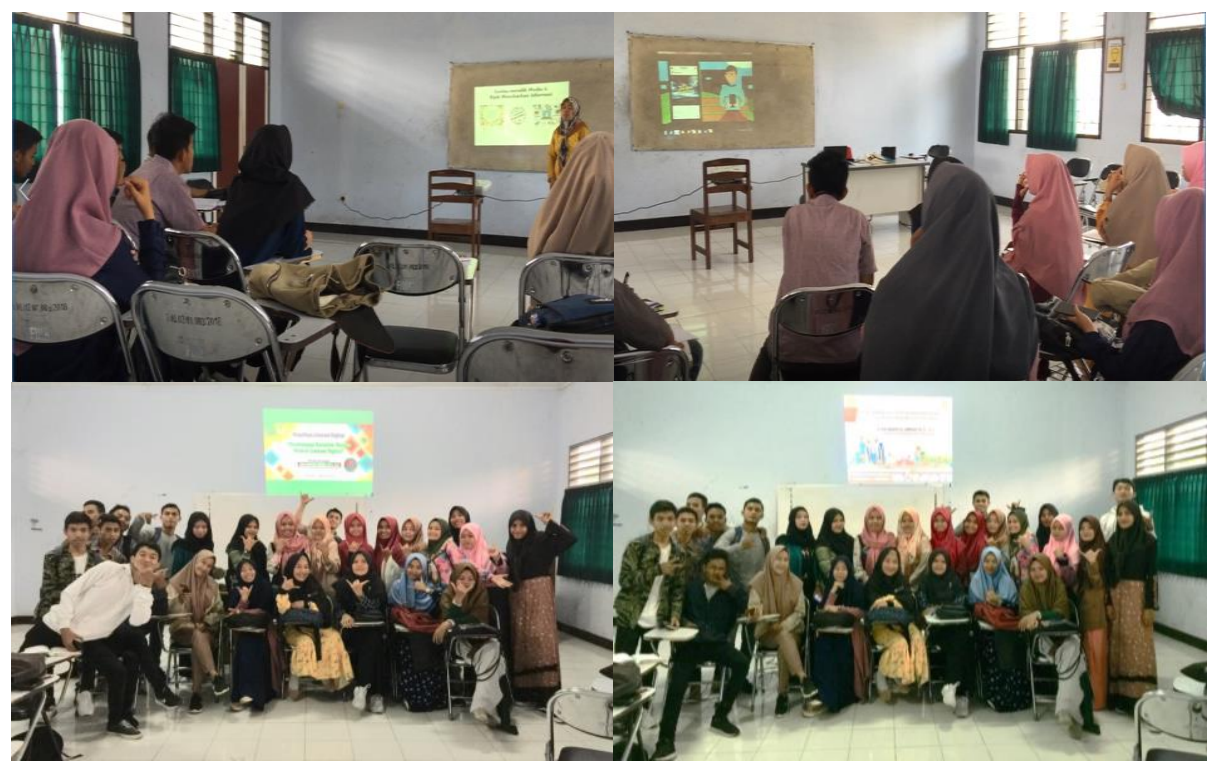

Gambar 2. Kegiatan Pelatihan Literasi Digital

Berdasarkan hasil pre-test dan post-test diketahui bahwa peserta pelatihan lietrasi digital mengalami peningkatan kompetensi literasi digital. Dimana sebelum pelatihan kompetensi literasi digital secara rata-rata sebesar 37\%. Angka ini artinya kompetensi literasi digital kurang. Selanjutnya setelah pelatihan literasi digital, kompetensi litereasi digital meningkat sebesar 72\%. Angka ini artinya peserta memiliki kompetensi literasi digital yang baik. 


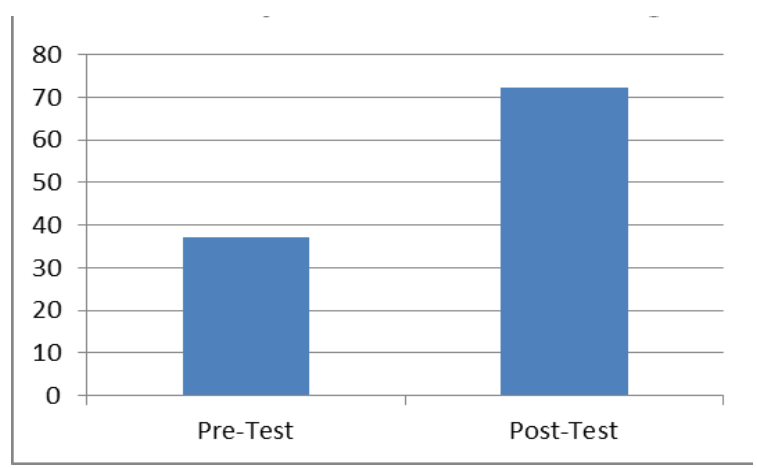

Gambar 2. Perbandingan kompetensi literasi digital peserta pelatihan sebelum dan sesudah pelatihan literasi dgital

Selanjutnya, pada kegiatan praktik dan follow up, peserta pelatihan menginisiasi untuk mencoba membuat blog atau website sebagai media alternatif mereka untuk menuangkan segala ide dan tulisan agar tersimpan baik dalam media digital. Serta sebagai sumber informasi dan refensi yang dapat dipercaya dan dipertanggungjawabkan.

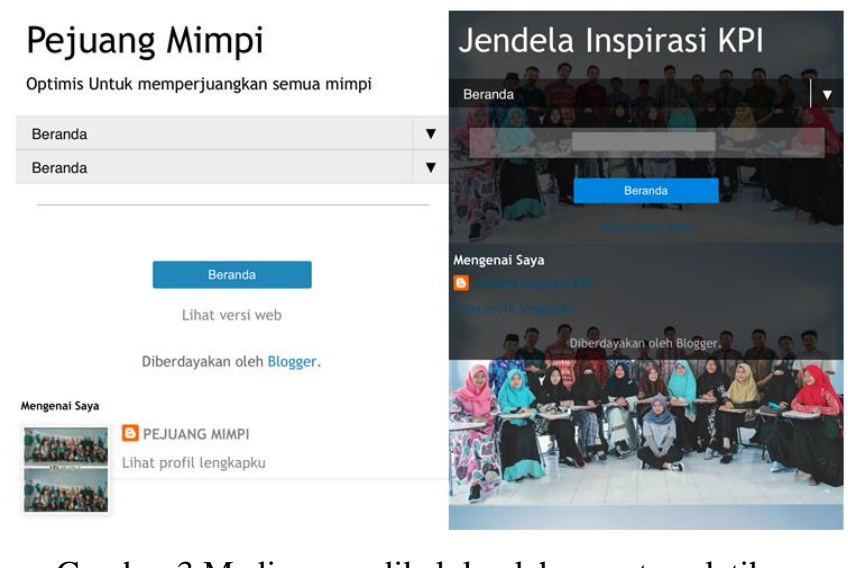

Gambar 3 Media yang dikelola oleh peserta pelatihan

Pada tahap evaluasi, dilakukan bersama peserta pelatihan dengan menggunakan metode diskusi dan sharing. Hasil evaluasi menunjukkan bahwa pelatihan literasi digital sangat bermanfaat untuk peserta pelatihan, terutama dua tema besar yang diangkat sangat erat kaitannya dengan kebutuhan dan kehidupan akademis dan kehidupan sehari-hari. Kedua, kegiatan pelatihan literasi digital semacam ini diharapkan dilaksanakan kembali dengan tema lain yang menarik, kemasan yang berbeda, dan lebih banyak praktek secara langsung.

Adapun beberapa capaian yang diperoleh dari kegiatan pelatihan literasi digital, diantaranya: Pertama, peserta mampu mengakses jurnal dan buku 


\section{INTEGRITAS : Jurnal Pengabdian}

Vol 4, No 2, Desember 2020

ISSN $2580-7978$ (cetak) ISSN 2615 - 0794 (online)

elektronik. Kemampuan ini penting dimiliki karena sangat dibutuhkan sebagai sumber rujukan, terutama untuk menulis artikel maupun makalah. Kedua, peserta pelatihan mampu mengidentifikasi informasi yang benar atau hoax serta mengevaluasi kebenaran informasi. Peserta telah mengetahui situs atau portal untuk melihat akurasi sebuah informasi, baik yang dimiliki oleh pemerintah maupun lembaga media massa. Ketiga, peserta membuat konten positif atau informasi yang akurat dan benar yang disebarkan di media sosial, seperti facebook, twitter, instagram, whatsapp, dll. Selain itu peserta juga membuat konten positif berupa meme. Meme merupakan literasi bahasa yang tersebar di internet, berupa penggalan percakapan yang disajikan secara unik dan kreatif.

Ketiga kompetensi ini menjadi penting dimiliki oleh generasi muda saat ini. Menelusuri dan membaca informasi di internet membutuhkan kemampuan atau keterampilan khusus, di tengah banyaknya informasi yang sulit dibedakan mana yang valid, terpercaya, benar, maupun sebaliknya. Lalu, setelah memiliki kemampuan tersebut, maka akan dengan mudah menulis atau membuat konten yang positif untuk disampaikan kepada khalayak dengan benar. Penyampaian informasi atau konten positif ini penting di tengah maraknya informasi yang sulit dibedakan antara yang benar dan salah di masyarakat. Dalam konteks saat ini, generasi muda atau mahasiswa memiliki peran strategis sebagai agen perubahan untuk membantu mengatasi berbagai persoalan masyarakat digital.

\section{KESIMPULAN}

Kegiatan pengabdian berupa pelatihan literasi digital kepada kelompok muda atau net generation ini dapat memberikan manfaat berupa peningkatan kemampuan literasi digital para peserta yang telah mengikuti pelatihan. Selain itu, kegiatan ini juga dapat memberikan kontribusi dalam pengembangan keilmuan dalam kajian media dan ilmu komunikasi, bahwa literasi digital menjadi isu penting yang perlu diperhatian dan dikaji. Selain itu kajian terkait informasi palsu atau fake news atau hoax menjadi kajian penting di era digital.

Adapun rekomendasi yang dapat diberikan adalah, kegiatan pelatihan serupa atau dalam bentuk kegiatan lain dapat dilakukan dengan kelompok dan kriteria peserta yang berbeda, misalnya kelompok guru, siswa, santri, dan lain sebagainya. 
INTEGRITAS : Jurnal Pengabdian

Vol 4, No 2, Desember 2020

ISSN 2580 - 7978 (cetak) ISSN 2615 - 0794 (online)

Hal ini untuk memperluas kebermanfaatan literasi digital yang sangat dibutuhkan

oleh semua kalangan. Karena perubahan adalah keniscayaan, maka setiap orang dituntut untuk mempunyai keterampilan dan kemampuan dalam menghadapi perubahan tersebut, salah satunya perubahan teknolog informasi dan komunikasi.

\section{UCAPAN TERIMA KASIH}

Kegiatan pengabdian ini berjalan dengan baik karena dukungan dari berbagai pihak, diantaranya Rektor Universitas Islam Negeri Mataram, Dekan Fakultas Dakwah dan Ilmu Komunikasi beserta jajaran, Ketua Program Studi Komunikasi dan Penyiaran Islam, serta pihak-pihak yang telah membantu dalam teknis pelaksanaan kegiatan pengabdian. Tanpa ada dukungan berupa izin pelaksanaan kegiatan di kampus dan juga support secara moril, kegiatan ini tidak akan terlaksana. Semoga kegiatan ini mendapatkan manfaat untuk lembaga dan masyarakat luas. Terima kasih.

\section{DAFTAR PUSTAKA}

Davis, Charles H. and Debora Shaw. (2011). Introduction to Information Science and Technology. Information Today: New Jersey.

Gilster, Paul. (1997). Digital Literacy. New York: Wiley.

Kurnia, Novi dan Indra Astuti. (2017). Peta Gerakan Literasi Digital di Indonesia: Studi Tentang Pelaku, Ragam Kegiatan, Kelompok Sasaran, dan Mitra. Jurnal Iinformasi Kajian Ilmu Komunikasi Volume 47. Nomor 2. Desember 2017.

Mastel-Masyarakat Telematika Indonesia. (2017). Hasil Survey Mastel Tentang Wabah Hoax Nasional. Jakarta: 13 Februai 2017.

MediaIndonesia.com (2018). 12 Provinsi Rawan penyebaran Hoax. https://mediaindonesia.com/read/detail/143254-12-provinsirawanpenyebaranhoax. (31 Januari 2018).

Narasuman, Suthagar Md., Rizal Md., Yunus and Azlan Ahmad Kamal. (2011). Net Generation Student Teachers: How Teach-Savvy Are They?. Asia Pacific Journal of Educators and Education, Vol. 26, No. 1, 71-89, 2011.

Tirto.id. (2018) Jerat UU ITE Banyak Dipakai oleh Pejabat Negara. https://tirto.id/jerat-uu-ite-banyak-dipakai-oleh-pejabat-negara-c7sk (18 Oktober 2018).

We are Social and Hootsuite. (2019). Digital Around the World 2019. We Are Social and Hootsuite Report. 